\title{
DINAMISASI KABINET DAN UPAYA KONSISTENSI SISTEM PRESIDENSIAL DI INDONESIA
}

\author{
Muh. Cendekiawan Ainul Haq \\ Fakultas Hukum Universitas Brawijaya, Malang, \\ datacend@gmail.com \\ Mohamad Rifan \\ Fakultas Hukum Universitas Brawijaya, Malang, \\ 12rauna@gmail.com \\ Resa Yuniarsa Hasan \\ Fakultas Hukum Universitas Brawijaya, Malang, \\ resahasan96@gmail.com
}

\begin{abstract}
Abstrak
Dinamisasi kabinet kerja yang merupakan hak prereogratif presiden tidak hanya memperhatikan resistensi antara presiden dengan kepentingan partai politik, namun juga pertimbangan antara eksistensi Pemerintah Daerah sebagai konsekuensi dari sistem Presidensil dalam bentuk Negara Kesatuan Republik Indonesia. Tulisan ini berusaha menelaah topik pembahasan Dinamisasi Kabinet dan Upaya Konsistensi Sistem Presidensial di Indonesia. Metode penelitian ini adalah yuridis normatif dengan pendekatan historis, pendekatan konseptual, dan pendekatan peraturan perundang-undangan. Hasil dalam pembahasan ini menyimpulkan bahwa postur kabinet harus dibarengi dengan sinkornisasi hukum hingga pada titik minimum postur pemerintahan (Pemerintah Daerah) dengan Pemerintah Pusat yang direpresentasikan oleh kementerian melalui UU Nomor 23 Tahun 2014 tentang Pemerintah Daerah dengan UU Nomor 39 tahun 2008 tentang Kementerian. Bentuk sinkornisasi tersebut dapat dilakukan melalui: Penambahan unsur profesionalisme dalam UU, Penambahan peraturan terkait komposisi, dan/atau syarat, dalam penambahan/ pengubahan/ penghapusan kementerian, dan penambahan pengaturan terkait harmonisasi kewenangan dan ruang kerja antara pusat dan daerah.
\end{abstract}

Kata kunci: Dinamisasi, Kabinet, Pemerintah.

\section{Abstact}

The dynamism of the working cabinet, which is the president's prerequisite, not only takes into account the resistance between the president and the interests of political parties, but also the consideration between the existence of the Regional Government as a consequence of the 
Presidency system in the form of the Unitary State of the Republic of Indonesia. This paper attempts to examine Cabinet Dynamics and Efforts to Consistency in the Presidential System in Indonesia. This research method is juridical normative with a historical approach, a conceptual approach, and a statutory approach. The results of this discussion conclude that the cabinet posture must be accompanied by legal syncornization to the minimum point of government posture (Regional Government) with the Central Government represented by the ministry through Law Number 23 of 2014 concerning Regional Government with Law Number 39 of 2008 concerning Ministries. This form of syncornization can be carried out through: Adding elements of professionalism in laws, adding regulations related to composition, and/or requirements, adding/ changing/ deleting ministries, and adding regulations related to harmonization of authority and work space between the central and regional governments.

Keywords: Cabinet, Dynamism, State Government

\section{PENDAHULUAN}

Menyoal tentang hubungan antara keberdaan kabinet dalam kementerian negara dan otonomi daerah dalam negara kesatuan merupakan hal yang berkontradiksi (contradictio in terminis) dengan konsep negara dengan sistem pemerintahan presidensiil. Berikut hubungannya dalam pemisahan kekuasaan Presiden sebagai kepala negara (head of state) dan kepala pemerintahan (head of government), ${ }^{1}$ serta dilakukan atas dasar pertimbangan pemisahan kekuasaan. Sistem ketatanegaraan Indonesia mengalami perubahan mendasar sejak adanya amendemen Undang-Undang Dasar Negara Republik Indonesia Tahun 1945 (UUD NRI Tahun 1945) yang dilakukan Majelis Permusyawaratan Rakyat (MPR) pada tahun 1999 hingga $2002 .^{2}$ Ambruknya rezim otoritarian menjadi penyebab utama (causa prima) yang mengawali proses transisi dari otoritarianisme menuju demokrasi konstitusional di Indonesia. ${ }^{3}$ Ciri dasar dari sebuah negara yang menerapkan demokrasi adalah hidupnya partai politik dan berlangsungnya pemilihan umum secara periodik. ${ }^{4}$ Amendemen Konstitusi telah mengubah

1 Franko Johner, Indra Perwira, Susi Dwi H., "Negara Bangsa Pos-Kolonial Sebagai Basis Dalam Menentukan Identitas Konstitusi Indonesia: Studi Terhadap UndangUndang Dasar 1945”, Jurnal Bina Mulia Hukum, Volume 2, Nomor 2, Maret 2018, h. 148.

2 Perubahan Pertama disahkan pada tanggal 19 Oktober 1999, Perubahan Kedua disahkan pada tanggal 18 Agustus 2000, Perubahan Ketiga disahkan pada tanggal 10 November 2011, dan Perubahan Keempat disahkan pada tanggal 10 Agustus 2002.

${ }^{3}$ Satya Arinanto, Hak Asasi Manusia dalam Transisi Politik di Indonesia, Jakarta: Pusat Studi Hukum Tata Negara Fakultas Hukum Universitas Indonesia, 2008, h. 98.

4 Yogo Pamungkas, "Tinjauan Ambang Batas Perolehan Suara Berdasarkan Undang-Undang Nomor 8 Tahun 2012 tentang Pemilihan Anggota Dewan Perwakilan 
skema dan format kelembagaan negara, mulai dari lembaga yang memiliki tingkatan paling tinggi sampai kepada lembaga yang memiliki tingkatan paling rendah. ${ }^{5}$ Pada masa transisi demokrasi telah memaksa Pemerintah untuk melakukan eksperimentasi kelembagaan (institutional experimentation). Akibatnya, banyak lembaga negara yang dihapus dan dibentuk dalam rangka memformulasikan struktur kelembagaan negara yang sesuai dengan tuntutan konstitusi yang telah di reformasi. Reformulasi struktur kelembagaan negara itu juga berimbas pada keberadaan Kabinet, sebagai lembaga pemerintah yang berada di dalam lingkungan Lembaga Kepresidenan. ${ }^{6}$

Presiden merupakan kepala kekuasaan eksekutif (head of executive) dalam negara sebagai lembaga negara yang melaksanakan undang-undang. ${ }^{7}$ Ketentuan konstitusi itu menunjukkan bahwa sistem pemerintahan yang dianut di Indonesia adalah sistem pemerintahan presidensil. ${ }^{8}$ Sejalan dengan hal tersebut, pada sistem pemerintahan presidensiil, titik berat kekuasaan dan tanggung jawab penyelenggaraan pemerintahan negara berada di tangan Presiden (concentration of power and responsibility upon the President). ${ }^{9}$ Sistem yang telah dirumuskan dan disepakati oleh para pendiri bangsa (the founding fathers) sejak sebelum kemerdekaan itu merupakan prinsip pemerintahan konstitusional (constitutional government) yang menjadi ciri penting negara hukum (staatsrecht) modern. ${ }^{10}$ Sistem pemerintahan presidensiil tetap dipertahankan sebagai salah satu bagian dari lima hal dasar (vijffundamentele) dari UUD NRI Tahun 1945 yang tidak dapat diubah. ${ }^{11}$

Rakyat, Dewan Perwakilan Daerah dan Dewan Perwakilan Rakyat Daerah Terhadap Undnag-Undang Dasar 1945”, Jurnal Rechtsvinding, Volume 3 Nomor 1, April 2014, h. 34 .

5 Jimly Asshiddiqie, Perkembangan dan Konsolidasi Lembaga Negara Pasca Reformasi, Jakarta: Konstitusi Press, 2006, h. 350.

6 Letak keduanya yang berada di lingkungan Istana Negara menyebabkan pengamanan disekeliling Sekretariat Negara dan Sekretariat Kabinet, atau sering disebut ring satu Presiden, dijaga ketat oleh Pasukan Pengamanan Presiden dari unsur Tentara Nasional Indonesia, sesuai ketentuan Pasal 7 ayat (2) huruf b angka 7 Undang-Undang Nomor 34 Tahun 2004 tentang Tentara Nasional Indonesia

${ }^{7}$ Lihat Penjelasan Pasal 4 UUD 1945.

${ }^{8}$ Mohammad Hatta, Menuju Negara Hukum, Jakarta: Yayasan Idayu, 1975, h. 11.

9 Jimly Asshiddiqie, Implikasi Perubahan UUD 1945 terhadap Pembangunan Hukum Nasional, Jakarta: Mahkamah Konstitusi Republik Indonesia, 2005, h. 9-10. vide Penjelasan UUD 1945 bagian Sistem Pemerintahan Negara angka IV.

10 Jimly Asshiddiqie, Pokok-Pokok Hukum Tata Negara Indonesia Pasca Reformasi, Jakarta: Bhuana Ilmu Populer, 2007, h. 328.

${ }^{11}$ Majelis Permusyawaratan Rakyat, Panduan dalam Memasyarakatkan UndangUndang Dasar Negara Republik Indonesia Tahun 1945: Latar Belakang, Proses, dan Hasil 
Rumusan Pasal 4 Ayat (1) UUD NRI Tahun 1945 ada kekuasaan pemerintahan negara yang menurut Undang-Undang Dasar dan ada pula kekuasaan pemerintahan negara yang tidak menurut Undang-Undang Dasar. ${ }^{12}$ Frasa 'menurut Undang-Undang Dasar' itu masih dapat dibedakan antara secara eksplisit ditentukan dalam Undang-Undang Dasar dan tidak secara eksplisit ditentukan dalam Undang-Undang Dasar. ${ }^{13}$ Namun meskipun demikian, pemaknaan Pasal 4 Ayat (1) UUD NRI Tahun 1945 masih sama, yakni Presiden tetap memiliki jabatan sebagai Kepala Pemerintahan Negara Republik Indonesia. ${ }^{14}$

Kekuasaan yang diberikan UUD NRI Tahun 1945 kepada Presiden sebagai pemegang kekuasaan pemerintahan (pouvoir executif) yang tertinggi dalam sistem pemerintahan presidensiil. ${ }^{15}$ Dari hal tersebut, jelas bahwa Presiden diberi kekuasaan yang besar oleh Konstitusi sehingga tanggung jawab yang dibebankan kepadanya juga besar (with great power comes great responsibility). ${ }^{16}$ Namun meskipun diberi kekuasaan yang besar, dalam menjalankan kekuasaannya Presiden senantiasa diawasi oleh DPR atas dasar prinsip checks and balances yang dianut Konstitusi. Bahkan, Presiden dapat diberhentikan dalam masa jabatannya apabila melakukan pelanggaran hukum, sebagaimana ditentukan dalam UUD NRI Tahun 1945. ${ }^{17}$ Kekuasaan penyelenggaraan pemerintahan yang dimiliki Presiden sebagai lembaga eksekutif, juga ada yang bersifat umum dan ada yang bersifat khusus. Kekuasaan penyelenggaraan pemerintahan yang bersifat umum adalah kekuasaan menyelenggarakan administrasi negara, sedangkan kekuasaan penyelenggaraan pemerintahan yang bersifat khusus adalah kekuasaan untuk menyelenggarakan tugas dan wewenang pemerintahan yang secara konstitusional ada pada pribadi Presiden yang memiliki sifat prerogatif (di bidang pemerintahan). ${ }^{18}$

Perubahan Undang-Undang Dasar Negara Republik Indonesia Tahun 1945, Jakarta: Sekretariat Jenderal Majelis Permusyawaratan Rakyat Republik Indonesia, 2003, h. 25.

12 Jimly Asshiddiqie, Pokok-Pokok Hukum, h. 333.

${ }^{13}$ Ibid.

${ }^{14}$ Maria Farida Indrati S., Ilmu Perundang-Undangan: Jenis, Fungsi, dan Materi Muatan, Yogyakarta: Kanisius, 2007, h. 130.

15 Abdul Ghoffar, Perbandingan Kekuasaan Presiden Indonesia Setelah Perubahan UUD 194 5dengan Delapan Negara Maju, Jakarta: Kencana, 2009, h. 96-120.

${ }^{16}$ Dalam Pembukaan UUD NRI Tahun 1945 Alinea Keempat, Presiden memiliki tanggung jawab untuk membentuk suatu Pemerintah Negara Indonesia yang melindungi segenap bangsa Indonesia dan seluruh tumpah darah Indonesia dan memajukan kesejahteraan umum, mencerdaskan kehidupan bangsa, dan ikut melaksanakan ketertiban dunia yang berdasarkan kemerdekaan, perdamaian abadi, dan keadilan sosial.

${ }^{17}$ Lihat Pasal 7A dan 7B Ayat (2) UUD NRI Tahun 1945

${ }^{18}$ Bagir Manan, Lembaga Kepresidenan, Yogyakarta: FH UII Press, 2003, h. 122. 
Dalam praktiknya, kekuasaan Presiden sebagai kepala negara sering disebut dengan istilah 'hak prerogatif', yaitu hak istimewa yang dimiliki oleh lembaga-lembaga tertentu yang bersifat mandiri dan mutlak dalam arti tidak dapat digugat oleh lembaga negara lain. Di dalam negara demokrasi manapun juga tetap diakui hak prerogatif Presiden bagi kepala negara, yang memberikan hak dan tanggung jawab yang luar biasa kepada kepala negara. ${ }^{19}$ Kekuasaan prerogatif melekat pada Presiden sebagai alat kelengkapan negara dan karena diputus untuk dan atas nama negara maka hak prerogatif itu bersifat konstitusional, baik ruang lingkup maupun batasbatasnya. ${ }^{20}$ Pada sistem pemerintahan negara modern, hak prerogatif itu dinyatakan dalam konstitusi dan tidak lagi bersifat mutlak dan mandiri, kecuali dalam hal pengambilan kebijakan dalam rangka penyelenggaraan pemerintahan. ${ }^{21}$

Salah satu kekuasaan prerogatif yang diberikan UUD NRI Tahun 1945 kepada Presiden dalam rangka penyelenggaraan pemerintahan adalah kekuasaan untuk mengangkat dan memberhentikan menteri, ${ }^{22}$ sebagaimana diatur dalam ketentuan Pasal 17 Ayat (2) UUD NRI Tahun 1945. ${ }^{23}$ Kekuasaan itu diberikan karena Presiden memerlukan bantuan Menteri untuk membantunya dalam melaksanakan berbagai macam urusan pemerintahan dan menjalankan segala perangkatnya. ${ }^{24}$ Ketentuan tersebut memberi wewenang kepada Presiden untuk menyusun dan mengatur setiap lembaga pemerintah yang berada di bawahnya dalam rangka membantu

${ }^{19}$ Z.A. Ahmad, Badan Eksekutif Negara, Jakarta: Bulan Bintang, 1952, h. 13.

${ }^{20}$ Bagir Manan dan Kuntana Magnar, Beberapa Masalah Hukum Tata Negara Indonesia, Bandung: Alumni, 1997, h. 160.

${ }^{21}$ Ibid., Di dalam UUD NRI Tahun 1945 memang tidak pernah dinyatakan istilah kekuasaan atau hak prerogatif Presiden, namun dalam kenyataannya h.ini terjadi dalam praktik ketatanegaraan Indonesia yang menggunakan sistem pemerintahan presidensiil, contohnya dalam hal pengangkatan menteri atau pejabat negara.

22 Anwar Gelora Mahardika, "Konvensi Ketatanegaraan Dalam Sistem Hukum Nasional di Indonesia Pasca Era Reformasi", Jurnal Rechtsvinding, Volume 8, Nomor 1, April 2019, h. 62.

${ }^{23}$ Ketentuan Pasal 17 ayat (2) UUD 1945 merupakan salah satu pasal yang diubah dalam Perubahan Pertama UUD 1945. Perubahan terhadap pasal itu untuk menyesuaikan dengan kaidah tata bahasa, dimana kata "diperberhentikan" disempurnakan menjadi "diberhentikan".

${ }^{24}$ Perhatikan ketentuan Pasal 1 angka1 dan angka 2 Undang-Undang Nomor 39 Tahun 2008 tentang Kementerian Negara yang memberi definisi Menteri dan kementerian. Menteri adalah pembantu Presiden yang memimpin suatu kementerian yang membidangi urusan tertentu dalam pemerintahan, sedangkan kementerian adalah perangkat pemerintah yang membidangi urusan tertentu dalam pemerintahan. 
penyelenggaraan urusan pemerintahan. ${ }^{25}$ Kekuasaan pengangkatan dan pemberhentian (appointment and removal) personel pemerintahan ini menjadi alat utama Presiden untuk menjaga soliditas tim kepresidenannya, seperti reshuffle kabinet. ${ }^{26}$ Kekuasaan Presiden itulah yang memungkinkan jumlah kementerian dalam setiap kabinet pemerintahan senantiasa bervariasi. ${ }^{27}$ Terkait dengan hal tersebut, semua corak, bentuk, bangunan, dan struktur organisasi dalam suatu negara hanya mencerminkan respon pengambil keputusan (decision maker) dalam mengorganisasikan berbagai kepentingan yang timbul dalam masyarakat, sehingga apabila kepentingan itu berkembang dengan dinamis maka organisasi negara juga berkembang dengan dinamikanya sendiri.

Pembatasan kekuasaan prerogatif Presiden ialah pembatasan jumlah kementerian yang dapat dibentuk Presiden dalam kabinet pemerintahannya. ${ }^{28}$ Kekuasaan prerogatif Presiden seolah dicampuri ketika DPR mengambil alih inisiatif penyusunan Rancangan Undang-Undang tentang Kementerian Negara dari Pemerintah. Di dalam rancangan yang akhirnya telah disahkan menjadi Undang-Undang Nomor 39 Tahun 2008 tentang Kementerian Negara (UU Kementerian Negara) itu, Presiden hanya dapat membentuk paling banyak 34 kementerian. ${ }^{29}$ DPR beralasan pembatasan jumlah kementerian itu tidak ditujukan untuk mengurangi apalagi menghilangkan hak Presiden dalam menyusun kementerian yang akan membantunya dalam menyelenggarakan urusan pemerintahan tetapi justru memudahkan Presiden dalam menyusun kementerian karena kedudukan, tugas, fungsi, dan susunan organisasi kementerian diatur secara

25 Retno Saraswati, "Desain Sistem Pemerintahan Presidensial yang Efektif", Jurnal Masalah-Masalah Hukum, Jilid 41, Nomor 1, Januari 2012, h. 140.

${ }^{26}$ Clinton Rossiter, The American Presidency, Harcourt, Brace: 1960, h. 6-7. Lihat dalam, Denny Indrayana, Negara Antara Ada dan Tiada: Reformasi Hukum Ketatanegaraan, Jakarta: Buku Kompas, 2008, h. 206.

${ }^{27}$ Jimly Asshiddiqie, Perkembangan dan Konsolidasi, h. 1.

${ }^{28}$ Ribkha Annisa Ocotvina, "Sistem Presidensial di Indonesia”, Cosmogov: Jurnal Ilmu Pemerintahan, Volume 4, Nomor 2, Oktober 2018, h. 248.

${ }^{29}$ Ketentuan Pasal 15 Undang-Undang Nomor 39 Tahun 2008. Undang-Undang itu disahkan pada tanggal 6 November 2008, Lembaran Negara Republik Indonesia Tahun 2008 Nomor 166. Mahkamah Konstitusi pernah melakukan pengujian undang-undang (constitutional review) terhadap ketentuan Pasal 10 ayat (2) dan (3), Pasal 11 ayat (3), Pasal 20, Pasal 33 ayat (1) dan ayat (2), serta Pasal 56 Undang-Undang Nomor 39 Tahun 2008 yang dimohonkan oleh Hj. Lily Chadidjah Wahid. Dalam Putusan Nomor 151/PUUVII/2009 tanggal 19 Mei 2010, parahakim Mahkamah Konstitusi menyatakan bahwa permohonan tidak dapat diterima. Mahkamah Konstitusi, "Putusan Sidang", http://www.mahkamahkonstitusi.go.id/putusan/putusan_sidang_ 2009 030610.pdf, diakses pada tanggal 25 Maret 2021. no_151-PUU-VII- 
jelas dan tegas (dalam Undang-Undang). ${ }^{30}$ Pengaturannya pun tidak menggunakan pendekatan pemberian nama tertentu pada setiap kementerian tetapi melalui pendekatan urusan pemerintahan yang harus dijalankan Presiden secara menyeluruh dalam rangka pencapaian tujuan negara. ${ }^{31}$ Berdasarkan Undang-Undang itu, urusan tertentu dalam pemerintahan diklasifikasikan menjadi tiga jenis, yaitu:

a. Urusan pemerintahan yang nomenklatur kementeriannya disebutkan secara tegas dalam UUD NRI Tahun 1945, meliputi urusan luar negeri, dalam negeri, dan pertahanan;

b. Urusan pemerintahan yang ruang lingkupnya disebutkan dalam UUD NRI Tahun 1945, meliputi urusan agama, hukum, keuangan, keamanan, hak asasi manusia, pendidikan, kebudayaan, kesehatan, sosial, ketenagakerjaan, industri, perdagangan, pertambangan, energi, pekerjaan umum, transmigrasi, transportasi, informasi, komunikasi, pertanian, perkebunan, kehutanan, peternakan, kelautan, dan perikanan; serta

c. Urusan pemerintahan dalam rangka penajaman, koordinasi, dansinkronisasi program pemerintah, meliputi urusan perencanaanpembangunan nasional, aparatur negara, kesekretariatan negara, badanusaha milik negara, pertanahan, kependudukan, lingkungan hidup, ilmupengetahuan, teknologi, investasi, koperasi, usaha kecil dan menengah, pariwisata, pemberdayaan perempuan, pemuda, olahraga, perumahan, dan pembangunan kawasan atau daerah tertinggal. ${ }^{32}$

Dari ketiga jenis urusan pemerintahan itu, terhitung ada 46 urusan yang menjadi tanggung jawab konstitusional Presiden dalam mencapai tujuan negara. Dengan mengetahui banyaknya urusan yang menjadi tanggung jawab Presiden itu. Dalam UUD NRI Tahun 1945 telah menentukan bahwa Presiden dibantu oleh seorang Wakil Presiden dan para menteri, dimana Wakil Presiden dibentuk untuk membantu pelaksanaan kewajiban Presiden sebagai pemegang kekuasaan pemerintahan dan menteri dibentuk untuk membantu Presiden dalam melakukan urusan tertentu dalam pemerintahan. ${ }^{33}$

Berkenaan dengan pertanggungjawaban kementerian kepada Presiden dan hubungannya dengan otonomi daerah yang dibidangi oleh kementerian tertentu dalam pemerintahan tidak memiliki hal yang berkesinambungan. Hal tersebut terkuak dalam dasar hukum yang melandasi antara keberadaan kementerian negara dan pemerintahan daerah. Keberadaan pemerintahan daerah sendiri memiliki potensi dalam mewujudkan demokratisasi karena proses desentralisasi mensyaratkan

\footnotetext{
${ }^{30}$ Penjelasan Umum Alinea Keempat Undang-Undang Nomor 39 Tahun 2008.

${ }^{31}$ Penjelasan Umum Alinea Kelima Undang-Undang Nomor 39 Tahun 2008.

32 Ketentuan Pasal 4 dan Pasal 5 Undang-Undang Nomor 39 Tahun 2008.

${ }^{33}$ Ketentuan Pasal 4 Ayat (2) dan Pasal 17 Ayat (1) UUD NRI Tahun 1945.
} 
adanya responsivitas, keterwakilan, dan akuntabilitas. ${ }^{34}$ Tujuan perwujudan pembentukan kabinet dalam kementerian negara sebagai salah satu hak prerogatif Presiden, dalam rangka penajaman, koordinasi, dan sinkronisasi program pemerintah masih mengalami kekaburan antara konteks harmonisasi antara penajaman, koordinasi, dan sinkronisasi program Pemerintah dengan program Pemerintah Daerah. sehingga dalam hal restrukturisasi kementerian baik dengan pembentukan maupun pengubahan wajib pula mempertimbangkan dampak dalam adaptasi di tingkat daerah. Hal ini juga tertuang dalam pembubaran kementerian, yang tidak jelas alasan yang mendasarinya, ditambah dengan keikutsertaan DPR.

Dengan demikian, dalam konsep negara kesatuan yang dianut dengan sistem pemerintahan presidensil, menjadi menarik untuk ditelusuri secara ilmiah berdasarkan hukum yang berlaku saat ini, antara keberadaan kabinet dalam kementerian negara sebagai bentuk hak prerogatif Presiden guna terwujudnya tujuan negara sebagaimana yang tertulis dalam Pembukaan Undang-Undang Dasar Negara Republik Indonesia Tahun 1945. Untuk mempermudah penarikan terhadap relasi antara eksistensi kabinet dalam kementerian negara dan pemerintah daerah yang terakomodir dalam konstitusi, penulis penggunakan istilah dinamisasi dalam keilmuan lain yang mana berarti optik dalam melihat perkembangan keragaman serta pemberian symbol atas relasi fungsi serta kewenangan yang dalam hal ini fokus pada Postur Kabinet. Sehingga berdasarkan pada pemaparan sebelumnya, problematika yang diangkat dalam tulisan ini dibatasi dalam 1 (satu) rumusan yaitu: Dinamisasi Kabinet dan Upaya Konsistensi Sistem Presidensial di Indonesia.

\section{METODE PENELITIAN}

Metode penelitian ini adalah yuridis normatif, yakni merupakan metode pengkajian atas norma-norma yang berkaitan dengan permasalahan dalam penelitian ini. Sedangkan pendekatan yang digunakan dalam penelitian ini adalah pendekatan historis, pendekatan konseptual, dan pendekatan peraturan perundang-undangan. Bahan hukum yang digunakan dalam penelitian ini terdiri dari bahan hukum primer berupa peraturan perundang-undangan dan bahan hukum berupa pendapat ahli hukum, jurnal, hasil penelitian, artikel ilmiah, dan website yang terkait dengan penelitian ini.

34 Diana Yusyanti, "Dinamika Hukum Pemilihan Daerah Menuju Proses Demokrasi Dalam Otonomi Daerah", Jurnal Rechtsvinding, Volume 4, Nomor 1, April 2015, h. 86. 


\section{PEMBAHASAN}

Sistem pemerintahan presidensial yang dianut oleh Indonesia, meletakkan Presiden sebagai pusat kekuasaan eksekutif dan pusat kekuasaan negara. Terdapat beberapa ciri sistem pemerintahan presidensial yang dinyatakan oleh beberapa ahli dari perspektifnya masing-masing. Seperti dalam pandangan Mahfud MD terkait dengan 4 (empat) poin ciri-ciri sistem presidensial, ${ }^{35}$ pandangan Jimly Asshiddiqie terkait dengan 9 (sembilan) ciri-ciri pemerintahan presidensial, ${ }^{36}$ dan terakhir pandangan Saldi Isra terkait dengan 4 (empat) ciri-ciri pemerintahan presidesial, ${ }^{37}$

Berdasarkan pada garis besar pendapat para ahli, penulis menyimpulkan bahwa sistem pemerintahan parlementer menempatkan peran dari kepala negara sebagai simbolis yang mempunyai kekuasaan politik terbatas. Kepala negara dan kabinet sebagai eksekutif berkedudukan lebih rendah dari parlemen dan bertanggung jawab kepadanya. ${ }^{38}$ Adapun posisi

${ }^{35}$ Dalam pandangannya, sistem presidensial berciri sebagai berikut: Kepala negara juga menjadi kepala pemerintahan; Pemerintah atau Presiden tidak bertanggungjawab pada parlemen; Menteri-menteri diangkat dan bertanggungjawab kepada Presiden; Eksekutif dan legislatif sama-sama kuat. Moh. Mahfud MD, Dasar dan Struktur Ketatanegaraan Indonesia, Jakarta: Rineka Cipta, 2001, h. 74.

36 Dalam pandangannya terdapat 9 ciri negara dengan sistem pemerintahan presidensial yaitu: Terdapat pemisahan kekuasaan yang jelas antara cabang kekuasaan eksekutif dan legislatif; Presiden merupakan eksekutif tunggal. Kekuasaan eksekutif Presiden tidak dapat dibagi dan yang ada hanya Presiden dan wakil Presiden saja; Kepala pemerintahan adalah sekaligus kepala negara atau sebaliknya yaitu kepala negara sebagai kepala pemerintahan; Presiden mengangkat para menteri sebagai pembantu Presiden atau sebagai bawahan yang bertanggungjawab kepadanya; Anggota parlemen tidak boleh menduduki jabatan eksekutif dan begitupun sebaliknya; Presiden tidak dapat membubarkan parlemen atau memaksa parlemen; Jika dalam sistem parlemen berlaku prinsip supremasi parlemen, maka dalam sistem presidensial berlaku prinsip supremasi konstitusi. Karena itu, pemerintahan eksekutif bertanggung jawab kepada konstitusi; Eksekutif bertanggung jawab langsung kepada rakyat yang berdaulat; Kekuasaan tersebar secara tidak terpusat seperti dalam sistem parlementer yang terpusat pada parlemen.

${ }^{37}$ berdasarkan ciri-ciri sistem pemerintahan presidensial, mengemukakan kekuatan atau kelebihan dari sistem tersebut, yaitu: Pertama, dengan dipilih secara langsung, kekuasaan Presiden menjadi lebih legitimate karena mendapat mandat langsung dari rakyat yang memilihnya; Kedua, pemisahan antara lembaga-lembaga negara terutama antara pemegang kekuasaan eksekutif dengan pemegang kekuasaan legislatif yang logika dari pemisahan ini adalah setiap lembaga negara dapat melakukan pengawasan terhadap lembaga negara lainnya untuk mencegah terjadinya penumpukan dan penyalahgunaan kekuasaan; Ketiga, dengan posisi sentral dalam jajaran eksekutif, Presiden dapat mengambil kebijakan strategis yang amat menentukan secara cepat. Keempat, dengan masa jabatan yang tetap, posisi Presiden jauh lebih stabil. Saldi Isra, Pergeseran Fungsi Legislasi: Menguatnya Model Legislasi Parlementer dalam Sistem Presidensial Indonesia, Jakarta: Raja Grafindo Persada, 2010, h. 42.

${ }^{38}$ Muliadi Anangkota, "Klasifikasi Sistem Pemeirntahan, Perspektif Pemerintahan Modern Kekinian", Cosmogov: Jurnal Ilmu Pemerintahan, h. 151. 
dari sistem pemerintahan campuran yang disusun atas sistem pemerintahan presidensial dan parlementer dapat dilihat perbedaan signifikannya pada tabel berikut: ${ }^{39}$

Tabel 1: Perbedaan Sistem Presidensial dan

Parlementer

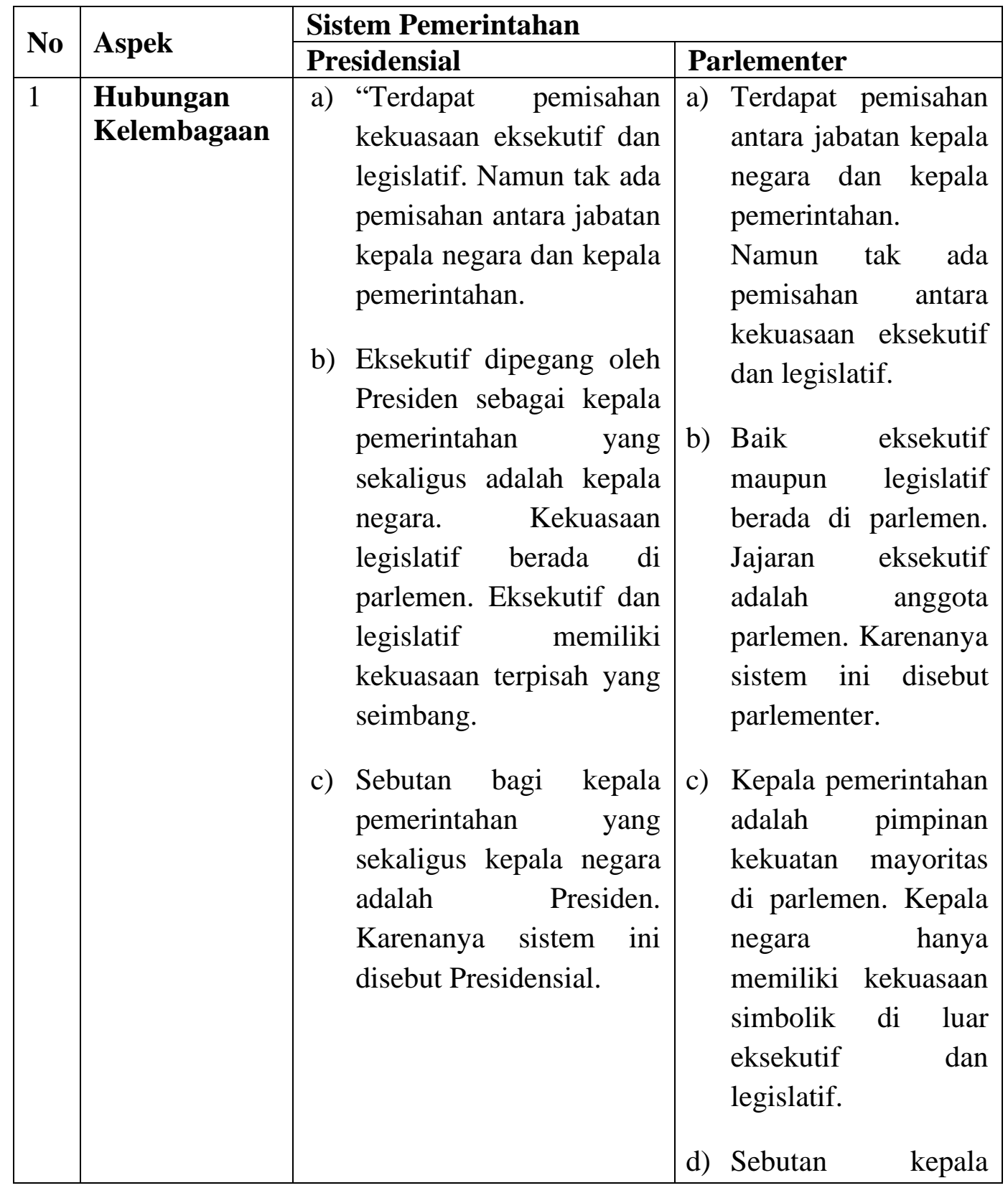

${ }^{39}$ Ibid., h. 52-53. 


\begin{tabular}{|c|c|c|c|}
\hline \multirow{2}{*}{ No } & \multirow{2}{*}{ Aspek } & \multicolumn{2}{|l|}{ Sistem Pemerintahan } \\
\hline & & Presidensial & Parlementer \\
\hline & & & $\begin{array}{l}\text { pemerintahan } \\
\text { perdana menteri. } \\
\text { Sebutan kepala } \\
\text { negara Presiden, raja, } \\
\text { ratu, dan lain-lain. }\end{array}$ \\
\hline 2 & $\begin{array}{l}\text { Pola } \\
\text { Rekrutmen }\end{array}$ & $\begin{array}{l}\text { a) Tak ada tumpang tindih } \\
\text { personal antara lembaga } \\
\text { eksekutif dan legislatif. } \\
\text { b) Anggota legislatif dipilih } \\
\text { langsung melalui } \\
\text { pemilihan umum. } \\
\text { c) Pimpinan eksekutif, } \\
\text { Presiden dan wakil } \\
\text { Presiden, dipilih langsung } \\
\text { melalui pemilihan umum. } \\
\text { d) Jajaran eksekutif lini } \\
\text { kedua, para menteri, } \\
\text { diangkat oleh Presiden. }\end{array}$ & 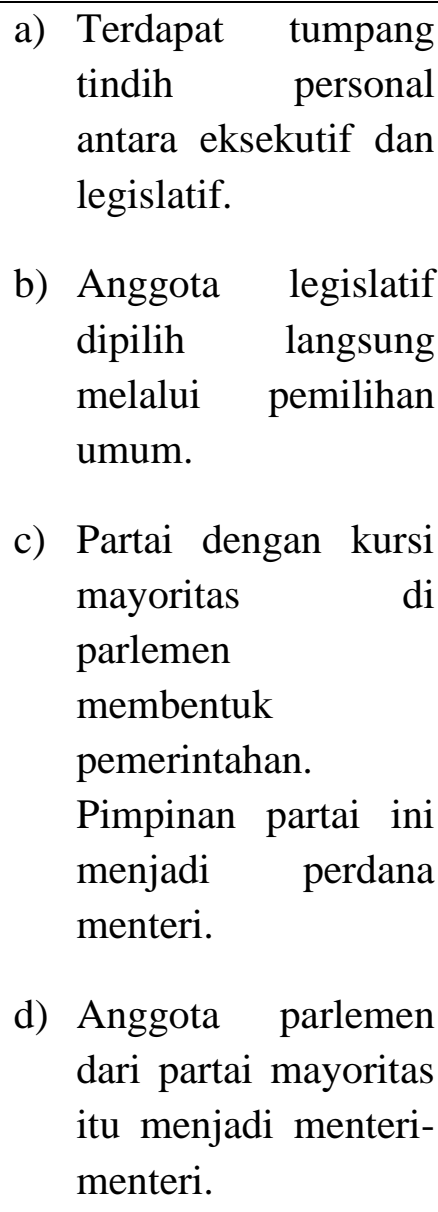 \\
\hline 3 & $\begin{array}{l}\text { Pola } \\
\text { Pengawasan } \\
\text { dan } \\
\text { Pertanggungj }\end{array}$ & $\begin{array}{l}\text { a) Terdapat mekanisme } \\
\text { check and balances antara } \\
\text { eksekutif dan legislatif. }\end{array}$ & $\begin{array}{l}\text { a) Terdapat mekanisme } \\
\text { pemerintah-oposisi } \\
\text { dalam legislatif. }\end{array}$ \\
\hline & awaban & $\begin{array}{lr}\text { b) Legislatif } & \text { menyusun } \\
\text { perundangan, } & \text { namun }\end{array}$ & $\begin{array}{lll}\text { b) Partai } & & \text { kekuatan } \\
\text { kedua di } & \text { parlemen }\end{array}$ \\
\hline
\end{tabular}




\begin{tabular}{|c|c|c|c|}
\hline \multirow{2}{*}{ No } & \multirow{2}{*}{ Aspek } & \multicolumn{2}{|l|}{ Sistem Pemerintahan } \\
\hline & & Presidensial & Parlementer \\
\hline & & $\begin{array}{l}\text { memerlukan pelaksanaan } \\
\text { oleh eksekutif. } \\
\text { c) Eksekutif bisa memveto } \\
\text { kebijakan legislatif, atau } \\
\text { menolak untuk } \\
\text { melaksanakan } \\
\text { perundangan, namun } \\
\text { legislatif memiliki hak } \\
\text { untuk meng-impeach } \\
\text { eksekutif. } \\
\text { d) Presiden sebagai } \\
\text { pimpinan eksekutif } \\
\text { memiliki hak untuk } \\
\text { mengangkat pejabat } \\
\text { negara, namun } \\
\text { memerlukan persetujuan } \\
\text { legislatif. } \\
\text { e) Legislatif tidak bisa } \\
\text { memberhentikan Presiden } \\
\text { dan Presiden tidak bisa } \\
\text { membubarkan eksekutif. }\end{array}$ & $\begin{array}{lr}\text { membentuk oposisi. } & \text { Pimpinan partai ini } \\
\text { menjadi } & \text { ketua } \\
\text { oposisi, anggota- } & \text { angota } \\
\text { anggota } & \text { partai } \\
\text { lainnya menjadi } & \text { anggota kabinet } \\
\text { bayangan sehingga } \\
\text { disebut pula sebagai } \\
\text { menteri-menteri } \\
\text { bayangan. } \\
\text { c) Kebijakan di } \\
\text { pemerintah } \\
\text { diperdebatkan } \\
\text { parlemen dengan } \\
\text { pihak oposisi sesuai } \\
\text { dengan lingkup } \\
\text { masing-masing. } \\
\text { d) Legislatif dapat } \\
\text { membubarkan } \\
\text { pemerintahan dengan } \\
\text { mosi tidak percaya } \\
\text { dan mendesakkan } \\
\text { pemilu untuk } \\
\text { memilih anggota } \\
\text { parlemen baru." }\end{array}$ \\
\hline
\end{tabular}

Indonesia pada awal kemerdekaan menganut sistem presidensial, namun dalam perjalannya tidak konsisten menganut sistem tersebut, tetapi pada akhir tahun 1945 telah bergeser pada sistem parlementer, terlebih dengan berlakunya konstitusi RIS dan UUDS, baru setelah dekrit presiden mulai kembali pada presidensial. Saat setelah reformasi kita mendapatkan penegasan itu dalam kesepakatan dasar MPR tentang arah perubahan UUD 1945 untuk mempertahankan sistem pemerintahan presidensial, namun tidak 
ada penegasan secara resmi dalam konstitusi, akan tetapi ciri-ciri sistem presidensial dapat kita temukan dalam UUD 1945 pasca perubahan. ${ }^{40}$ Seperti Pasal 4 ayat (1) dimana Presiden RI memegang kekuasaan pemerintahan menurut UUD, Pasal 7 dimana Presiden dan Wakil Presiden memegang jabatan selama lima tahun, Pasal 7C dimana Presiden tidak dapat membekukan dan/atau membubarkan DPR, Kedudukan Presiden sebagai kepala negara, dan Pasal 17 dimana Presiden dibantu oleh menteri-menteri negara, menteri-menteri itu diangkat dan diberhentikan oleh Presiden. ${ }^{41}$

Fokus dalam kewenangan presiden untuk mengangkat dan memberhentikan menteri. ${ }^{42}$ Konstruksi dalam penyusunan postur kabinet sebagai implementasi dari prinsip presidensial dilandasi dengan eksisting dari Undang-Undang Nomor 39 Tahun 2008 tentang Kementerian Negara. Dalam konstruksi dari Undang-Undang tersebut, menyebutkan bahwa tidak hanya berlandaskan interpretasi sistematis, namun juga terdapat interpretasi politis. Posturing atas penyusunan komponen maupun kerangka dalam postur kabinet untuk lebih jelas dapat dibagi menjadi 4 (empat) bentuk, yaitu:

1. Pemilihan Personal Kabinet

Secara normatif, pemilihan personal yang mengisi jabatan dalam kabinet berdasarkan pada ketentuan pemenuhan kriteria sebagai berikut: ${ }^{43}$

a. warga negara Indonesia;

b. bertakwa kepada Tuhan Yang Maha Esa;

c. setia kepada Pancasila sebagai dasar negara, Undang-Undang Dasar Negara Republik Indonesia Tahun 1945, dan cita-cita proklamasi kemerdekaan;

d. sehat jasmani dan rohani;

e. memiliki integritas dan kepribadian yang baik; dan

f. tidak pernah dipidana penjara berdasarkan putusan pengadilan yang telah memperoleh kekuatan hukum tetap karena melakukan tindak pidana yang diancam dengan pidana penjara 5 (lima) tahun atau lebih.

40 Retno Saraswati, "Desain Sistem Pemerintahan Presidensial Yang Efektif", Jurnal Masalah-Masalah Hukum, Jilid 41 No. 1, Januari 2012, h. 139.

41 Sodikin, "Pemilu Serentak (Pemilu Legislatif dengan Pemilu Presiden dan Wakil Presiden) dan Penguatan Sistem Presidensial", Jurnal Rechtsvinding, Volume 3 Nomor 1, April 2014, h. 24.

42 Dinoroy Marganda Aritonang, "Penerapan Sistem Presidensil di Indonesia Pasca Amandemen UUD 1945”, Jurnal Mimbar Hukum, Volume 22, Nomor 2, Juni 2010, h. 395.

${ }^{43}$ Pasal 22 Undang-Undang Nomor 39 Tahun 2008 tentang Kementerian Negara. 
Dalam peraturan tersebut dapat dilihat bahwa prinsip dasar presidensialisme mengenai pengangkatan dan pemberhentian anggota kabinet merupakan hak mutlak presiden atau sering disebut sebagai hak prerogatif presiden ${ }^{44}$ dalam kabinet presidensial kedudukan presiden merupakan sentral kekuasaan eksekutif. Namun sayangnya, kelemahan dalam ketentuan pada pasal tersebut tidak tercantum pertimbangan atas profesionalisme atau kapasitas kementerian. Sehingga jabatan atas pengisian kabinet sering diopinikan dengan konsep presidensialisme saat ini di Indonesia hidup sejajar dengan eksisting multipartai pragmatis atau presidensialisme kompromis (compromisepresidentialism) yang kemudian berkonsekuensi cenderung memunculkan intervensi partai politik terhadap presiden dan sebaliknya presiden cenderung mengakomodasi kepentingan partai politik koalisi dalam menyusun kabinet. ${ }^{45}$ Sehingga kondisi eksisting atas ketentuan dalam norma ini menyebabkan hak prerogatif ini akan mengalami reduksi. Reduksi kekuasaan presiden akan semakin kuat apabila koalisi yang akan terbangun tidak memiliki kedekatan secara ideologis atau bersifat pragmatis atau berlawanan dengan nilai-nilai yang hidup dalam opsi Pembentukan/Pengubahan Kementerian

2. Pembentukan Kementerian,

Kementerian yang dapat dibentuk oleh presiden terdiri dari kementerian yang membantu urusan pemerintahan yang ruang lingkupnya disebutkan dalam Undang-Undang Dasar Negara Republik Indonesia tahun $1945,{ }^{46}$ dan urusan pemerintahan dalam rangka penajaman, koordinasi, dan sinkronisasi program pemerintah. ${ }^{47}$

44 Lihat dalam Pasal 11 Undang-Undang Nomor 39 Tahun 2008 tentang Kementerian Negara bahwa mengenai tugas, fungsi, dan susunan organisasi Kementerian diatur dengan Peraturan Presiden.

45 Konsekuensi dari pola demikian adalah munculnya model kabinet yang dipertimbangkan berdasarkan Koalisi dengan tingkat separasi ideologis dan komposisi yang berubah-ubah.

46 Pasal 5 ayat (2) UU Kementerian Negara, urusan tersebut meliputi urusan agama, hukum, keuangan, keamanan, hak asasi manusia, pendidikan, kebudayaan, kesehatan, sosial, ketenagakerjaan, industri, perdagangan, pertambangan, energi, pekerjaan umum, transmigrasi, transportasi, informasi, komunikasi, pertanian, perkebunan, kehutanan, peternakan, kelautan, dan perikanan.

47 Pasal 5 ayat (3) UU Kementerian Negara, urusan tersebut meliputi urusan perencanaan pembangunan nasional, aparatur negara, kesekretariatan negara, badan usaha milik negara, pertanahan, kependudukan, lingkungan hidup, ilmu pengetahuan, teknologi, investasi, koperasi, usaha kecil dan menengah, pariwisata, pemberdayaan perempuan, pemuda, olahraga, perumahan, dan pembangunan kawasan atau daerah tertinggal. 
Adapun pembentukan kementerian tersebut dibentuk dengan mempertimbangkan:

a. efisiensi dan efektivitas;

b. cakupan tugas dan proporsionalitas beban tugas;

c. kesinambungan, keserasian, dan keterpaduan pelaksanaan tugas; dan/atau

d. perkembangan lingkungan global.

Dalam hal pembentukan kementerian tersebut, pembentukan kementerian dalam rangka penajaman, koordinasi, dan sinkronisasi program pemerintah masih mengalami kekaburan antara konteks harmonisasi antara penajaman, koordinasi, dan sinkronisasi program Pemerintah Pusat dengan program Pemerintah Daerah. sehingga dalam hal restrukturisasi kementerian baik dengan pembentukan maupun pengubahan wajib pula mempertimbangkan dampak dalam adaptasi di tingkat daerah.

3. Pengubahan Kementerian,

Dalam hal pengubahan kementerian yang sama dengan pembentukan kementerian, pembentukan kementerian tersebut dibentuk dengan mempertimbangkan: ${ }^{48}$

a. efisiensi dan efektivitas;

b. perubahan dan/atau perkembangan tugas dan fungsi;

c. cakupan tugas dan proporsionalitas beban tugas;

d. kesinambungan, keserasian, dan keterpaduan pelaksanaan tugas;

e. peningkatan kinerja dan beban kerja pemerintah;

f. kebutuhan penanganan urusan tertentu dalam pemerintahan secara mandiri; dan/atau

g. kebutuhan penyesuaian peristilahan yang berkembang.

4. Penghapusan Kementerian,

Konstruksi dalam Undang-Undang Nomor 39 tahun 2008 belum menyebutkan secara tegas sebab-akibat dan pertanggungjawaban selain pembubaran oleh Presiden dengan meminta pertimbangan Dewan Perwakilan Rakyat, kecuali Kementerian yang menangani urusan agama, hukum, keuangan, dan keamanan harus dengan persetujuan Dewan Perwakilan Rakyat. Sehingga berbeda dengan pradigma dalam penambahan atau pengubahan Kementerian, dalam hal penghapusan tidak ditemukan latar belakang atas: efisiensi dan efektivitas; atau kesinambungan, keserasian, dan keterpaduan

${ }^{48}$ Dalam Pasal 18 ayat (2) UU Kementerian Negara. 
pelaksanaan tugas. Kondisi demikian menyebabkan penghapusan kementerian atau penyerderhanaan jumlah kementerian menjadi domain Presiden dan Dewan Perwakilan Rakyat.

Kondisi demikian apabila ditelaah dengan relasi atas efektifitas sistem presidensial ditentukan dalam 2 (dua) dimensi ${ }^{49}$ yaitu pertama, efektivitas Sistem (Institusional) yang menjelaskan bahwa relasi antar aktor dan institusi presidensialisme berjalan sesuai peraturan perundang-undangan yang berlaku. Kedua, Efektivitas Personalitas Presiden (Non Institusional). Titik temu atas kedua dimensi tersebut terdapat dalam kemampuan dan karakter personal presiden dalam menerapkan presidensialisme sesuai rumusan konstitusi. Berarti pembentukan kabinet oleh presiden harus memiliki resistensi dengan desakan intervensi oleh Partai Politik yang memiliki visi dan ideologi berbeda, Sehingga konsekuensi dari bentuk prinsip demikian maka proses pembentukan kabinet sepenuhnya berlandaskan hak prerogatif presiden.

Lebih lanjut, terkait pembahasan problematika yang timbul yang diakibatkan oleh problematika normatif seperti yang disebutkan sebelumnya. Dinamisnya perubahan postur kabinet kerja dalam tiap pergantian Rezim pemerintahan juga menjadi salah satu faktor dilematisasi, secara historigrafi komposisi kebijkan kabinet guna menyesuaikan kebutuhan presiden untuk menyusung programnya maka penggelembungan kelembagaan menjadi hal yang wajar dilakukan. Konstruksi dalam UndangUndang Nomor 39 tahun 2008 menyebutkan bahwa secara konsep seminimal mungkin terdapat 3 (tiga) kementerian dan maksimum 34 kementerian. tercatat di tahun 2014-2019 terdapat 34 Kementerian, 28 LPNK, dan 135 LNS. Realitas atas pertumbuhan lembaga pemerintah di pusat termasuk tinggi dengan tidak diiringi dengan perbaikan tingkat efesiensi, efektfitas, dan kinerja secara signifikan yang justru mengakibatkan penggelembungan kelembagaan. Terdapat jumlah Jabatan 19.478 di Kementerian dan 5.020 pejabat structural di LPNK. Banyaknya Jumlah kemnterian ini menempati posisi 4 di Indonesia. ${ }^{50}$

Dalam tahapan realitas sturktur kelembagaan tidak lepas dari postur kabinet yang dipilih berdasarkan hak prerogatif presiden guna menelisik stabilitas pemerintahan. ${ }^{51}$ Disamping titik idealnya dalam stabilitas

${ }^{49}$ Hanta Yuda AR, Presidensialisme Setengah Hati, Jakarta: Gramedia Pustaka Utama, 2010, h. 59.

${ }^{50}$ Pusat Kajian Kinerja Kelembagaan Deputi Bidang kelembagaan dan Sumber Daya Aparatur, Laporan Akhir Kajian Desain Kelembagaan Pemerintah Pusat (Arsitektur Kelembagaan Tahun 2014-2019), Jakarta: Lembaga Administrasi Negara, 2013, h. 32.

51 Bilal Dewansyah dan M. Adnan Yazar Zulfikar, "Reafirmasi Sistem Pemerintahan Presidensial dan Model Pertanggungjawaban Presidesial dalam Perubahan 
pemerintahan di struktur politik presidensial, partai presiden haruslah partai mayoritas, yaitu partai yang didukung suara mayoritas di parlemen. Kekuatan mayoritas ini diperlukan dalam parlemen, untuk menjamin stabilitas pemerintahan presiden terpilih agar presiden mudah mendapatkan dukungan secara politik dari parlemen guna melancarkan kebijakan politik yang dibuat presiden. Namun, suara mayoritas ini sulit diperoleh oleh partai presiden dalam situasi multipartai, kecuali mengandalkan koalisi partai politik di parlemen dan kabinet agar dapat meraih suara mayoritas untuk menjamin stabilitas pemerintahan.

Relasinya dengan negara Indonesia yang dalam konstitusi terarahkan sebagai Negara Kesatuan. Sebagaimana tertuang dalam Pasal 1 ayat 1 UUD NRI Tahun 1945 yang berbunyi "Negara Indonesia adalah Negara Kesatuan yang berbentuk Republik". Kemudian dipertegas dalam rumusan Pasal 18 ayat (1) yang menyatakan bahwa "Negara Kesatuan Republik Indonesia dibagi atas daerah-daerah provinsi dan daerah provinsi itu dibagi atas kabupaten dan kota, yang tiap-tiap provinsi, kabupaten, dan kota itu mempunyai pemerintahan daerah, yang diatur dengan undnagundang". ${ }^{52}$ Pasal 18 ayat (1) menjadi landasan konstitusional terbentuknya sistem desentralisasi di Indonesia. Melalui pasal tersebut juga secara implisit diterangkan bahwa negara Indonesia adalah Negara Kesatuan yang mana dalam pelaksanaannya menggunakan asas desentralisasi. Desentralisasi sendiri merupakan penyerahan kewenangan dari pemerintah pusat kepada pemerintah daerah untuk mengurusi urusan rumah tangganya sendiri berdasarkan prakarsa dan aspirasi dari rakyatnya dalam kerangka Negara Kesatuan Republik Indonesia. ${ }^{53}$

Mengenai bentuk negara, dalam Pasal 37 ayat (5) mengenai perubahan Undang-Undang Dasar yang menyatakan bahwa "Khusus mengenai bentuk Negara Kesatuan Republik Indonesia tidak dapat dilakukan perubahan". Melalui pasal inilah kita bisa melihat seberapa besar kekuatan the founding fathers negara kita untuk mempertahankan citra kesatuan dalam Negara Indonesia.

Dalam praktiknya, konsepsi Negara Kesatuan Republik Indonesia merupakan prinsip dasar dalam penyelenggaraan pemerintahan daerah dan

UUD 1945: Penlusuran Sebab dan Konsekuensi”, PADJAJARAN Jurnal Ilmu Hukum, Volume 3, Nomor 2, 2016, h. 289.

${ }_{52}$ M. Lutfi Chakim, "Perubahan Sistem Pemilihan Kepala Daerah Dalam Dinamika Pelaksanaan Demokrasi”, Jurnal Rechtsvinding, Volume 3 Nomor 1, April 2014, h. 116.

53 Eko Noer Kristiyanto, "Pemilihan Gubernur Tak Langsung Sebagai Penegasan Eksistensi Gubernur Sebagai Wakil Pemerintah Pusat di Daerah", Jurnal Rechtsvinding, Volume 1 Nomor 3, Desember 2012, h. 397. 
titik start melihat relasi antara kementerian dengan Pemerintah Daerah. ${ }^{54}$ Hal ini di satu sisi mengukuhkan keberadaan daerah sebagai bagian nasional, tetapi di sisi lain memberikan stimulan bagi masyarakat daerah untuk mengartikulasikan semua kepentingannya, termasuk masalah otonomi daerah dalam sistem hukum dan kebijakan nasional. ${ }^{55}$ Sehingga polemik yang terjadi adalah dibutuhkannya sinkornisasi dan harmonisasi antara Postur Kabinet dengan Pemerintah Daerah. Dengan problematika yang terjadi secara yuridis bahwa Undang-Undang Kementerian Negara sudah berada pada kebutuhan asupan penyesuaian dengan Undang-Undang Lainnya, dan Politis bahwa kekosongan hukum yang terdapat dalam ketentuan peraturan perundang-undangan berkait dan dengan penyusunan Kabinet mengakibatkan derasnya intervensi yang mereduksi hak prerogratif dari Presiden.

Problematika yang terjadi dalam tataran normatif terdapat pada konsep pemerintahan daerah yang direpresentasikan pada konteks original intent dari konsep kementerian di dalam 2 (dua) pasal pada 2 (dua) produk hukum yang berbeda. Dalam Pasal 1 angka 44 Undang-Undang Nomor 23 Tahun 2014 tentang pemerintahan Daerah disebutkan bahwa Menteri adalah menteri yang menyelenggarakan urusan pemerintahan dalam negeri yang terdiri dari:

1. Pasal 231 menteri yang menyelenggarakan Urusan Pemerintahan bidang pendayagunaan aparatur negara.

2. Pasal 245 ayat (2) dan ayat (4), Pasal 289 ayat (7), Pasal 300 ayat (2), dan sebagainya. menteri yang menyelenggarakan urusan pemerintahan bidang keuangan.

3. Pasal 245 ayat (2) menteri yang menyelenggarakan urusan pemerintahan bidang tata ruang.

4. Pasal 259 ayat (2) menteri yang menyelenggarakan urusan pemerintahan bidang perencanaan pembangunan.

${ }^{54}$ Dalam pasal 26 Undang Undang Nomor 39 Tahun 2008 tentang Kementerian Negara bahwa "Hubungan antara Kementerian dan pemerintah daerah dilaksanakan dalam kerangka sistem pemerintahan Negara Kesatuan Republik Indonesia dengan memperhatikan prinsip-prinsip penyelenggaraan otonomi daerah sesuai peraturan perundang-undangan."

${ }^{55}$ Hari Sabarno, Untaian Pemikiran Otonomi Daerah: Memandu Otonomi Daerah Menjaga Kesatuan Bangsa, Jakarta: Sinar Grafika, 2008, h. 144. 
5. Pasal 292 ayat (4) Menteri yang menyelenggarakan urusan pemerintahan bidang perencanaan pembangunan nasional.

Sedangkan dalam pasal 4 Undang-Undang Nomor 39 tahun 2008, kementerian meliputi urusan pemerintahan yang ruang lingkupnya disebutkan dalam Undang-Undang Dasar Negara Republik Indonesia Tahun 1945 dan urusan pemerintahan dalam rangka penajaman, koordinasi, dan sinkronisasi program pemerintah.

Dalam hal urusan pemerintahan yang ruang lingkupnya disebutkan dalam Undang-Undang Dasar Negara Republik Indonesia Tahun 1945 meliputi urusan agama, hukum, keuangan, keamanan, hak asasi manusia, pendidikan, kebudayaan, kesehatan, sosial, ketenagakerjaan, industri, perdagangan, pertambangan, energi, pekerjaan umum, transmigrasi, transportasi, informasi, komunikasi, pertanian, perkebunan, kehutanan, peternakan, kelautan, dan perikanan. Dalam hal urusan pemerintahan dalam rangka penajaman, koordinasi, dan sinkronisasi program pemerintah. meliputi urusan perencanaan pembangunan nasional, aparatur negara, kesekretariatan negara, badan usaha milik negara, pertanahan, kependudukan, lingkungan hidup, ilmu pengetahuan, teknologi, investasi, koperasi, usaha kecil dan menengah, pariwisata, pemberdayaan perempuan, pemuda, olahraga, perumahan, dan pembangunan kawasan atau daerah tertinggal.

Sehingga berdasarkan pada ketentuan diatas, sudah menjadi barang tentu terdapat Pekerjaan Ruman (PR) bagi Presiden dan Wakil Presiden untuk melakukan penyederhanaan postur kabinet hingga kelembagaan serta penyesuaian dengan kebutuhan Program Kerjanya. Identifikasi secara gramatikal bahwa terdapat 24 urusan yang dapat dilaksanakan kementerian, dan tidak semua harus dibentuk satu kementerian tersendiri. Di lain sisi karena tidak seluruhnya urusan tersebut diitentifikasikan sebagai bagian dari kementerian, maka Identifikasi komposisi tersebut diambil guna pembentukan Departemen, LNS, dan LPNK.

Inti dan pusat dari otonomi daerah itu sendiri adalah kebebasan masyarakat setempat untuk mengatur dan mengurus kepentingan sendiri yang bersifat lokalitas untuk terselenggaranya kesejahteraan. Dalam otonomi terdapat nilai yang hakiki, yakni nilai demokrasi dan prakarsa sendiri. Namun komposisi demikian tidak dapat lepas dari adanya hubungan antara pemeirntah pusat dan Pemerintah Daerah. Interpretasi atas model hubungan antara pemerintah pusat dan daerah menurut Clarke dan Stewart, dapat dibagi menjadi 3 (tiga) model yaitu model relatif, model agensi dan model interaksi. Pembeda antara ketiganya dapat dilihat dalam tabel berikut: 
Tabel 2: Politik Hukum 3 model hubungan kewenangan Pemerintah Pusat dan Pemerintah Daerah ${ }^{56}$

Sumber: Peraturan Perundang-Undangan, 2021

\begin{tabular}{|c|c|c|c|c|}
\hline No. & Indikator & Model Relatif & Model Agensi & Model Interaksi \\
\hline 1 & $\begin{array}{l}\text { Konsep } \\
\text { Umum }\end{array}$ & $\begin{array}{l}\text { Memberikan } \\
\text { kebebasan } \\
\text { pada } \\
\text { pemerintah } \\
\text { daerah dan } \\
\text { pada saat yang } \\
\text { sama tidak } \\
\text { mengingkari } \\
\text { realitas negara } \\
\text { bangsa, } \\
\text { penekanannya } \\
\text { adalah dengan } \\
\text { memberikan } \\
\text { kebebasan } \\
\text { bertindak pada } \\
\text { pemerintah } \\
\text { daerah dalam } \\
\text { rangka kerja } \\
\text { kekuasaan dan } \\
\text { kewajiban } \\
\text { yang } \\
\text { ditentukan. }\end{array}$ & $\begin{array}{c}\text { Pemerintah } \\
\text { daerah dilihat } \\
\text { terutama } \\
\text { sebagai agen } \\
\text { untuk } \\
\text { melaksanakan } \\
\text { kebijakan } \\
\text { pemerintah } \\
\text { pusat. }\end{array}$ & $\begin{array}{c}\text { Ruang lingkup } \\
\text { kegiatan } \\
\text { pemerintah } \\
\text { pusat dan } \\
\text { pemerintah } \\
\text { daerah sulit } \\
\text { ditentukan, } \\
\text { karena mereka } \\
\text { terlibat dalam } \\
\text { pola hubungan } \\
\text { yang rumah } \\
\text { dimana } \\
\text { penekananya } \\
\text { ada pada } \\
\text { pengaruh yang } \\
\text { menguntungkan. }\end{array}$ \\
\hline 2 & $\begin{array}{c}\text { Ruang } \\
\text { Lingkup }\end{array}$ & $\begin{array}{l}\text { Hubungan } \\
\text { pemerintah } \\
\text { pusat dan } \\
\text { daerah } \\
\text { ditentukan } \\
\text { oleh peraturan } \\
\text { perundang- } \\
\text { undangan dan } \\
\text { pengawasan } \\
\text { dibatasi. } \\
\text { pemerintah } \\
\text { daerah dapat }\end{array}$ & & \\
\hline
\end{tabular}

56 Dudung Abdullah, "Hubungan Pemerintah Pusat dengan Daerah", Jurnal Hukum POSITUM Vol. 1, No. 1, Desember 2016, h. 98-100. 


\begin{tabular}{|c|c|c|c|c|}
\hline No. & Indikator & Model Relatif & Model Agensi & Model Interaksi \\
\hline & & $\begin{array}{c}\text { membuat } \\
\text { kebijakan } \\
\text { yang dibagi } \\
\text { dengan } \\
\text { pemerintah } \\
\text { pusat atau } \\
\text { yang berbeda } \\
\text { dari kebijakan } \\
\text { yang dengan } \\
\text { pemerintah } \\
\text { pusat atau } \\
\text { yang berbeda } \\
\text { dari kebijakan } \\
\text { yang } \\
\text { ditetapkan } \\
\text { oleh } \\
\text { pemerintah } \\
\text { pusat. }\end{array}$ & & \\
\hline \multirow[t]{2}{*}{3} & \multirow[t]{2}{*}{ Implementasi } & \multicolumn{2}{|c|}{$\begin{array}{l}\text { Pasal } 7 \text { Undang-undang Nomor } \\
5 \text { Tahun } 1974 \text { tentang Pokok- } \\
\text { Pokok Pemerintah di Daerah }\end{array}$} & \\
\hline & & $\begin{array}{l}\text { Pasal } 1 \text { huruf } \\
\text { d dan pasal } 7 \\
\text { Undang- } \\
\text { undang } \\
\text { Nomor } 22 \\
\text { Tahun } 1999 \\
\text { tentang }\end{array}$ & & \\
\hline
\end{tabular}

57 Dalam pasal ini berisi bahwa "Daerah berhak, berwenang dan berkewajiban mengatur dan mengurus rumah tangganya sendiri sesuai dengan peraturan perundanganundangan yang berlaku". Konsep Undangundang ini menggunakan model Relatif, tetapi secara pelaksanaan tidak sesuai dengan konsep Undang-undang itu sendiri. H.tersebut dikarenakan pada era orde baru dimana kekuasaan pemerintah pusat sangat dominan yang mengaggap pemerintah daerah sebagai pemerintah pusat yang ada didaerah dan menjalankan fungsi perwakilan pemerintah pusat sehingga memunculkan kesan atau memang "sentralistik" dalam penyelenggaraannya. Artinya secara pelaksanaan pada era ini, menggunakan model "Agensi". Ada tiga prinsip dasar yang dianut oleh Undang-undang Nomor 5 Tahun 1974, yaitu desentralisasi, dekonsentrasi, dan tugas pembantuan. Prakteknya, prinsip dekonsentrasi lebih dominan. 


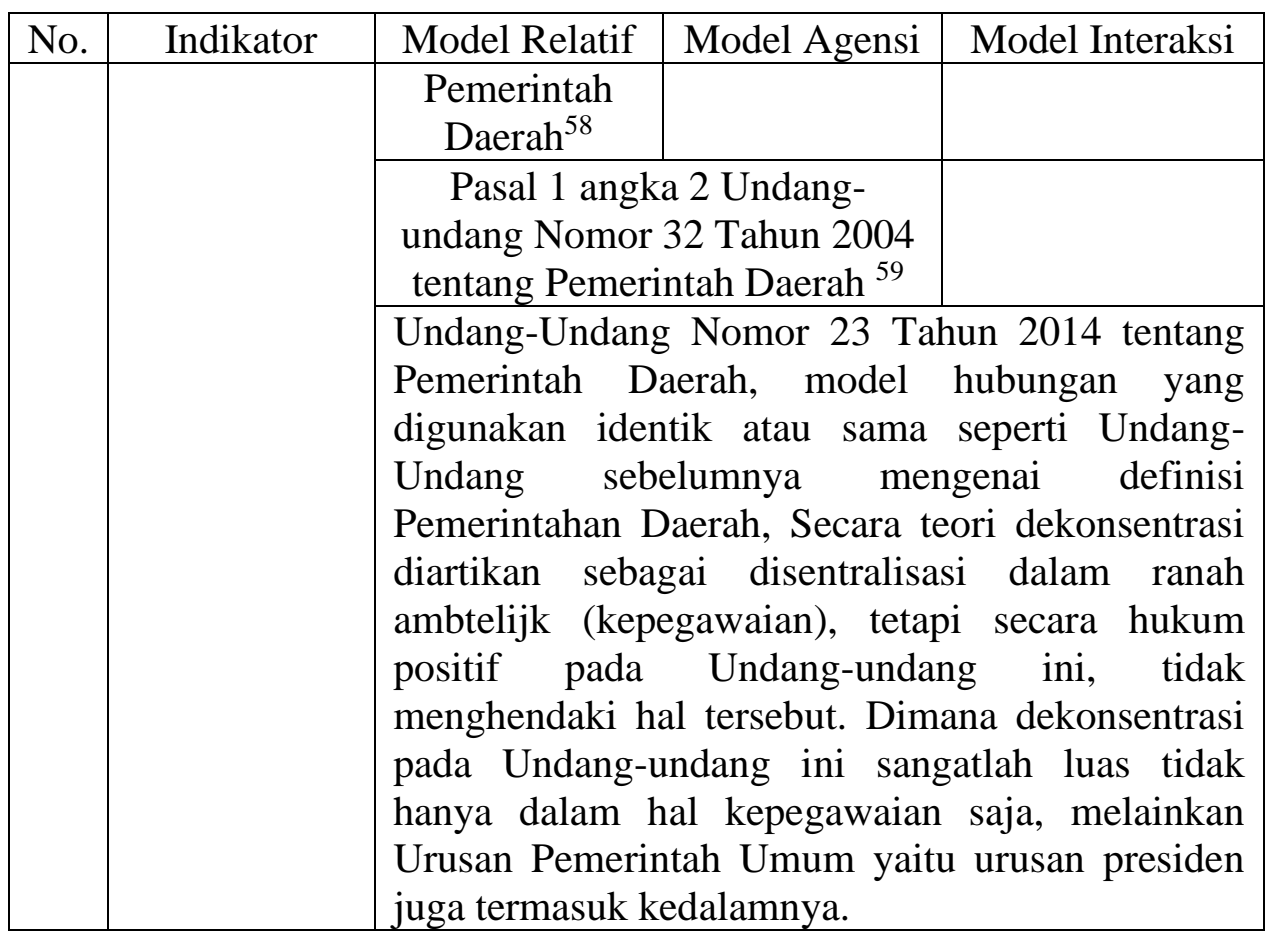

58 Dalam Undang-undang Nomor 22 Tahun 1999 tentang Pemerintah Daerah terlihat ada upaya untuk menghilangkan sistem "Sentralistik" pada penyelenggaraan pemerintahan, eksistensi Pemerintah Daerah (bukan pemerintah di daerah) yang dimasukkan dalam Pasal 1 huruf (d) ketentuan umum yang memiliki ketentuan: "Pemerintah Daerah adalah Penyelenggaraan Pemerintah Daerah Otonom oleh Pemerintah Daerah dan DPRD menurut asas Disentralisasi”. Tentang hubungan antara pemerintah pusat dan pemerintah daerah ditegaskan dalam Pasal 7 dengan ketentuan:“ Kewenangan Daerah mencakup kewenangan dalam seluruh bidangpemerintahan, kecuali kewenangan dalam bidang politik luar negeri,pertahanan keamanan, peradilan, moneter dan fiskal, agama, sertakewenangan bidang lain". Pada pasal diatas dapat dilihat adanya model yang digunakan Undang-undang ini lebih condong kepada model Relatif, karena Pemerintah Daerah diberikan kewenangan tetapi tetap dibatasi dalam kewenangan tertentu merupakan urusan pemerintah pusat yang berdampak nasional dan dapat mengganggu stabilitas negara.

59 Dalam Undang-undang Nomor 32 Tahun 2004 tentang Pemerintah Daerah disebutkan bahwa : "Pemerintahan daerah adalah penyelenggaraan urusan pemerintahan oleh pemerintah daerah dan DPRD menurut asas otonomi dan tugas pembantuan dengan prinsip otonomi seluas-luasnyadalam sistem dan prinsip Negara Kesatuan Republik Indonesia sebagaimana dimaksud dalam UndangUndang Dasar Negara Republik Indonesia Tahun 1945." Dari definisi diatas dapat kita lihat, penyelenggaraan urusan pemerintahan pusat oleh pemerintahan daerah dilakukan menurut Asas Otonomi yang sebelumnya asas disentralisasi. maka asas otonomi mengandung prinsip disentralisasi dan dekonsentrasi, sehingga h.tersebut mengakibatkan disatu sisi Model hubungan kewenangan Pemenrintah Pusat dengan daerah itu adalah "Model Relatif" (Desentralisasi), tetapi disisi lain menggunakan "Model Agensi" (dekonsentrasi dan Tugas Pembantuan) hanya sebatas bidang ambtelijk recht (Hukum Kepegawaian) dan Programprogram pemerintah pusat. 
Sehingga berdasarkan pada gambaran diatas, dapat dikatakan bahwa Prinsip negara kesatuan yang berbentuk republik dengan pelaksanaan otonomi daerah sesuai dengan asas desentalisasi, dekosentrasi, dan tugas pembantuan, merupakan filosofi dasar bagi Indonesia dalam melaksanakan konsep otonomi daerah dalam pelaksanaanya. Pelaksanaan asas-asas otonomi daerah, khususnya asas desentralisasi politik, tampak pada adanya perubahan relasi antara pemerintah pusat dan daerah. ${ }^{60}$ Optimasi antara ruang kerja Kabinet hingga Pemerintah daerah tetap diperlukan guna mencapai titik model interaksi dimana baik pemerintah pusat dan daerah terlibat dalam pola hubungan yang sistem rumah tangganya terfokus ada pada pengaruh yang menguntungkan (simbiosys mutualism). Pengaruh yang menguntungkan ini tergambar pada kondisi dimana terdapat sinkornisasi antara arah pembangunan pemerintah Daerah dengan program kerja Presiden dan Wakil Presiden yang direpresentasikan Kementerian. Oleh karenanya konstruksi yang dibentuk dalam telaah delineasi postur Kabinet dan Pemerintah Daerah akan mengalami level up sebagai berikut:

\section{Bagan 2: Konstruksi Delineasi Pemerintah Daerah Secara Fungsional}

Sumber: Kreasi Penulis, 2021

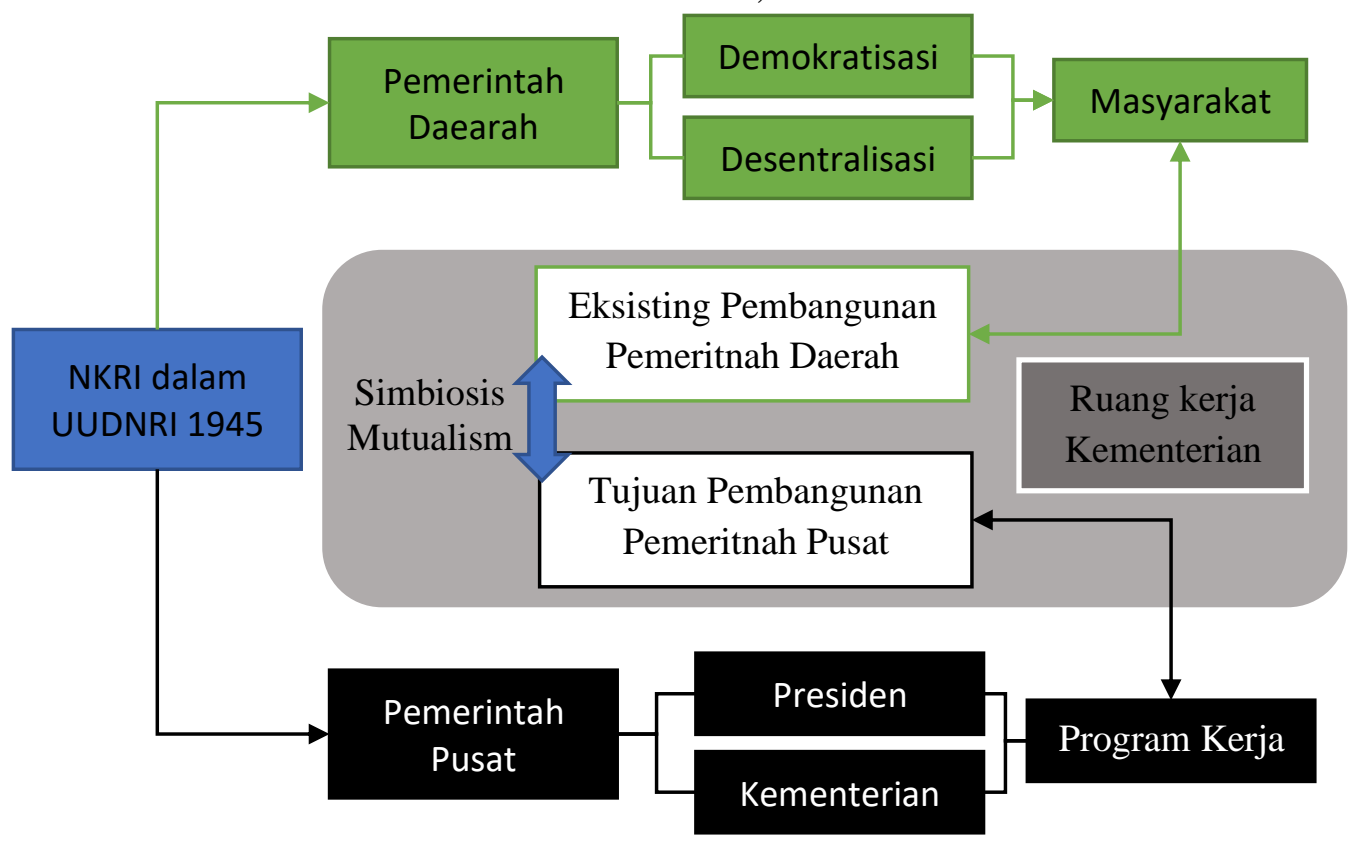

${ }^{60}$ Kacung Marijan, Sisem Politik Indonesia: Konsolidasi Demokrasi Pasca Orde Baru, Kencana, Surabaya: 2010, h. 153. 
Kondisi diatas apabila mempertimbangkan dengan konstruksi dalam pembahasan sebelumnya telah dipaparkan bahwa kompromi politik internal yang melemahkan sistem pemerintahan presidensiil tersebut antara lain: (1) tereduksinya hak prerogatif Presiden dalam menyusun kabinet; (2) kabinet yang terbentuk cenderung kabinet koalisi beberapa partai politik; (3) adanya potensi dualisme loyalitas menteri dari parpol yang menyulut konflik kepentingan; (4) terganggunya keharmonisan hubungan antara Presiden dan Wakil Presiden. ${ }^{61}$

\section{KESIMPULAN}

Dinamisasi kabinet kerja merupakan hak prereogratif presiden dan memperhatikan pola relasi presiden-partai politik. namun parpol hnya bersifat subordinat. pola ini ada di konstruksi parelemen, namun tunduk dan diangkat oleh presiden mnunjukan skema presidensial. Kondisi atas perubahan postur kabinet harus dibarengi dengan sinkornisasi hukum di antara Pemerintah Daerah dengan Pemerintah Pusat yang direpresentasikan oleh kementerian melalui UU Nomor 23 Tahun 2014 tentang Pemerintah Daerah dengan UU Nomor 39 tahun 2008 tentang Kementerian. Bentuk sinkornisasi tersebut dapat dilakukan melalui: Penambahan unsur profesionalisme dalam UU, Penambahan peraturan terkait komposisi, dan/ atau syarat, dalam penambahan/pengubahan/ penghapusan kementerian, dan penambahan pengatiran terkait harmonisasi kewenangan dan ruang kerja antara pusat dan daerah.

\section{DAFTAR PUSTAKA}

\section{Buku}

Abdul, Ghoffar, 2009, Perbandingan Kekuasaan Presiden Indonesia Setelah Perubahan UUD 1945 dengan Delapan Negara Maju, Jakarta: Kencana

Arinanto, Satya, 2008, Hak Asasi Manusia dalam Transisi Politik di Indonesia, Jakarta: Pusat Studi Hukum Tata Negara Fakultas Hukum Universitas Indonesia

Asshiddiqie, Jimly, 2005 Implikasi Perubahan UUD 1945 terhadap Pembangunan Hukum Nasional, Jakarta: Mahkamah Konstitusi Republik Indonesia

Asshiddiqie, Jimly, 2006, Perkembangan dan Konsolidasi Lembaga Negara Pasca Reformasi, Jakarta: Konstitusi Press

${ }^{61}$ Pada era Presiden Susilo Bambang Yudhoyono terjadi konflik internal berupa ketegangan antar partai yang berujung pada terganggunya keharmonisan hubungan Presiden dengan Wakil Presiden Jusuf Kalla. H.ini dikarenakan jumlah suara Partai Golkar (asal Wakil Presiden) di parlemen lebih besar ketimbang Partai Demokrat(asal Presiden)). 
Asshiddiqie, Jimly, 2007, Pokok-Pokok Hukum Tata Negara Indonesia Pasca Reformasi, Jakarta: Bhuana Ilmu Populer

Farida Indrati S., Maria, 2007, Ilmu Perundang-Undangan: Jenis, Fungsi, dan Materi Muatan, Yogyakarta: Kanisius

Indrayana, Denny, 2008, Negara Antara Ada dan Tiada: Reformasi Hukum Ketatanegaraan, Jakarta: Buku Kompas

Majelis Permusyawaratan Rakyat, 2003, Panduan dalam Memasyarakatkan Undang- Undang Dasar Negara Republik Indonesia Tahun 1945: Latar Belakang, Proses, dan Hasil Perubahan Undang-Undang Dasar Negara Republik Indonesia Tahun 1945, Jakarta: Sekretariat Jenderal Majelis Permusyawaratan Rakyat Republik Indonesia

Manan, Bagir dan Kuntana Magnar, 1997, Beberapa Masalah Hukum Tata Negara Indonesia, Bandung: Alumni

Marijan, Kacung, 2010, Sisem Politik Indonesia: Konsolidasi Demokrasi Pasca Orde Baru, Surabaya: Kencana

Pusat Kajian Kinerja Kelembagaan Deputi Bidang kelembagaan dan Sumber Daya Aparatur, 2013, Laporan Akhir Kajian Desain Kelembagaan Pemerintah Pusat (Arsitektur Kelembagaan Tahun 2014-2019), Jakarta: Lembaga Administrasi Negara

Sabarno, Hari, 2008, Untaian Pemikiran Otonomi Daerah: Memandu Otonomi Daerah Menjaga Kesatuan Bangsa, Jakarta: Sinar Grafika

Yuda AR, Hanta, 2010, Presidensialisme Setengah Hati, Jakarta: Gramedia Pustaka Utama

\section{Jurnal Ilmiah}

Abdullah, Dudung, 2016, "Hubungan Pemerintah Pusat dengan Daerah", Jurnal Hukum POSITUM, Volume 1, Nomor 1

Anwar Gelora Mahardika, 2019, "Konvensi Ketatanegaraan Dalam Sistem Hukum Nasional di Indonesia Pasca Era Reformasi”, Jurnal Rechtsvinding, Volume 8, Nomor 1

Aritonang, Dinoroy Marganda, 2010, "Penerapan Sistem Presidensil di Indonesia Pasca Amandemen UUD 1945", Jurnal Mimbar Hukum, Volume 22, Nomor 2

Bisariyadi, 2015, "Keterlibatan Mahkamah Konstitusi Dalam Politik Legislasi Nasional", Jurnal Rechtsvinding, Volume 4, Nomor 3

Dewansyah, Bilal dan M. Adnan Yazar Zulfikar, 2016, "Reafirmasi Sistem Pemerintahan Presidensial dan Model Pertanggungjawaban Presidesial dalam Perubahan UUD 1945: Penleusuran Sebab dan Konsekuensi”, PADJAJARAN Jurnal Ilmu Hukum, Volume 3, Nomor 2 
Kristiyanto, Eko Noer, 2012 "Pemilihan Gubernur Tak Langsung Sebagai Penegasan Eksistensi Gubernur Sebagai Wakil Pemerintah Pusat di Daerah", Jurnal Rechtsvinding, Volume 1 Nomor 3

Ocotvina, Ribkha Annisa Ocotvina, 2018, "Sistem Presidensial di Indonesia", Cosmogov: Jurnal Ilmu Pemerintahan, Volume 4, Nomor 2

Saraswati, Retno, 2012, "Desain Sistem Pemerintahan Presidensial Yang Efektif", Jurnal Masalah-Masalah Hukum, Jilid 41 No. 1

Sodikin, 2014, "Pemilu Serentak (Pemilu Legislatif dengan Pemilu Presiden dan Wakil Presiden) dan Penguatan Sistem Presidensial", Jurnal Rechtsvinding, Volume 3 Nomor 1

Yusyanti, Diana, 2015, "Dinamika Hukum Pemilihan Daerah Menuju Proses Demokrasi Dalam Otonomi Daerah”, Jurnal Rechtsvinding, Volume 4, Nomor 1

\section{Website}

Hj. Lily Chadidjah Wahid. Dalam Putusan Nomor 151/PUU-VII/2009 tanggal 19 Mei 2010, parahakim Mahkamah Konstitusi menyatakan bahwa permohonan tidak dapat diterima. Mahkamah Konstitusi, "Putusan Sidang", http://www.mahkamahkonstitusi.go.id/putusan/putusan_sidang_no_1 51-PUU-VII-2009_030610.pdf, diakses pada tanggal 25 Maret 2021

\section{Peraturan Perundang-Undangan}

Republik Indonesia, Undang-Undang Dasar Negara Republik Indonesia Tahun 1945.

Republik Indonesia, Undang-Undang Nomor 39 Tahun 2008 tentang Kementerian Negara, Lembaran Negara Republik Indonesia Tahun 2008 Nomor 166, Tambahan Lembaran Negara Republik Indonesia Nomor 4916. 